\title{
Clinical Results of Endoprosthetic Reconstruction in Malignant Tumors Around the Elbow
}

\author{
Dirsek Çevresi Malign Tümörlerde Endoprotetik \\ Rekonstrüksiyonun Klinik Sonuçları
}

Coskun Ulucakoy ${ }^{1}$,

Ismail Burak Atalay ${ }^{1}$,

Recep Ozturk',

Aliekber Yapar ${ }^{1}$,

Guray Togral',

Emek Mert Duman',

Bedii Safak Gungor ${ }^{1}$

${ }^{1}$ Department of Orthopaedics and Traumatology, Dr Abdurrahman Yurtaslan Ankara Oncology Training and Research Hospital, Ankara, Turkey

Geliş Tarihi/Received: 25 August 2020 Kabul Tarihi/Accepted: 4 November 2020

Öz

Amaç: Dirsek çevresindeki malign tümör nedeniyle tümör rezeksiyonu ve endoprotetik rekonstrüksiyon yapılan hastaların klinik sonuçlarının sunulması amaçlanmıştır.

Hastalar ve Yöntem: Kliniğimizde 2011-2018 yılları arasında dirsek çevresinde malign tümör nedeniyle tümör rezeksiyonu ve endoprotetik rekonstrüksiyon yapılan 14 hasta çalışmaya dahil edildi. Hastaların 4'ü primer tümör ( 1 fibromiksoid sarkom, 1 leimyosarkom, 1 multipl miyelom ve 1 ewing sarkom) iken 10'u uzak organ metastazı (4 meme kanseri, 3 akciğer kanseri, 1 mide kanseri, 1 renal hücre kanseri ve 1 tiroid) kanser) idi. Musculoskeletal Tumor Society (MSTS) skoru ve Mayo dirsek performans skoru (MEPS) ve sağkalımı değerlendirildi.

Bulgular: Hastaların minimum takip süresi 7 ay, maksimum takip süresi 55 aydı. Hastaların ortalama MEPS skoru 67,5 $\pm 12,0$ (aralık, 45-90) ve MSTS skorunun ortalaması 19,4 \pm 2.3 (aralık, 16-24) idi. 3 hastada takipte nüks, 7 hastada takipte exitus görüldü. Bu çalışmada hastaların medyan sağkalım süresi 44 aydı. 1 yıllık sağkalım oranı\% 70,1 iken 3 yıllık sağkalım oranı\% 54,5 idi.

Sonuç: Dirsek çevresindeki malign tümör nedeniyle tümör rezeksiyonu ve endoprotetik rekonstrüksiyon yapılan hastalarda ağrı ve fonksiyonel sonuçlar tatmin edicidir. Gelecekte daha geniş hasta serileri ile çalışmalara ihtiyaç vardır.

Address correspondence to: Coskun Ulucakoy, Dr. Abdurrahman Yurtaslan Oncology Hospital, Department of Orthopaedics \& Traumatology, Ankara, Turkey e-mail: coskunulucakoy@gmail.com

\section{ORCID}

Coskun Ulucakoy

https://orcid.org/0000-0002-6991-5511

Ismail Burak Atalay

https://orcid.org//0000-0002-6210-4193

Recep Ozturk

https://orcid.org/0000-0002-6753-9321

Aliekber Yapar

https://orcid.org/0000-0003-2227-2173

Guray Togral

https://orcid.org/0000-0002-2489-9335

Emek Mert Duman

https://orcid.org/0000-0002-4445-6718

Bedii Safak Gungor

https://orcid.org/0000-0002-1339-0840

\section{Abstract}

Aim: It was aimed to present the clinical and functional results of the patients who underwent tumor resection and endoprosthetic reconstruction due to malignant tumor around the elbow.

Patients and Methods: 14 patients who underwent tumor resection and endoprosthetic reconstruction due to malignant tumor in the elbow circumference between 2011-2018 in our clinic were included in the study. While 4 of the patients were primary tumors ( 1 fibromixoid sarcoma, 1 leimyosarcoma, 1 multiple myeloma and 1 ewing sarcoma), 10 were distant organ metastases (4 breast cancer, 3 lung cancer, 1 stomach cancer, 1 renal cell cancer and 1 thyroid cancer). Musculoskeletal Tumour Society (MSTS) score and Mayo elbow performance score (MEPS) and survival were evaluated

Results: The minimum follow-up period of the patients was 7 months, and the maximum follow-up period was 55 months. The mean MEPS score of the patients was $67.5 \pm 12.0$ (range, 45-90), and the mean of the MSTS score was $19.4 \pm 2.3$ (range, 16-24). Recurrence occurred at follow-up in 3 patients and exitus at follow-up in 7 patients. In this study, the median survival time of the patients was 44 months. The 1-year survival rate was $70.1 \%$ while the 3 -year survival rate was $54.5 \%$.

Conclusion: Pain and functional results are satisfactory in patients who undergo tumor resection and endoprosthetic reconstruction due to malignant tumor around the elbow. In the future, studies with larger

Key words: Endoprosthetic reconstruction, malignant tumor, elbow
Anahtar Kelimeler: Endoprotetik rekonstrüksiyon, malign tümör, dirsek patient series are needed.
Cite this article as: Ulucakoy C, Atalay IB, Ozturk R, Yapar A, Togral G, Duman EM, Gungor BS. Clinical Results of Endoprosthetic Reconstruction in Malignant Tumors Around the Elbow. Selcuk Med J 2020;36(4): 338-342

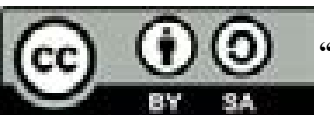

Disclosure: None of the authors has a financial interest in any of the products, devices, or drugs mentioned in this article. The research was not sponsored by an outside organization. All authors have agreed to allow full access to the primary data and to allow the journal to review the data if requested. 


\section{INTRODUCTION}

The elbow joint and distal humerus are rare sites for both primary malignant bone tumors and metastases (1). Since reconstructive surgeries have replaced amputations, the primary goal in elbow tumors has been to provide local control and maintain extremity functionality (2). Reconstruction options are limited after the resection of tumors around the elbow joint. Arthrodesis is not recommended due to large bone resection and the difficulty in preservation of the limb function (3). Total elbow arthroplasty is already used for non-tumor causes. In cases where more bone resection is performed, such as a tumor, resection prostheses are recommended for the elbow $(4,5)$. Studies on this subject are limited as the elbow joint is kept rare by tumors and subsequent endoprosthetic reconstruction applications are limited. Therefore, the aim of this study is to convey our experiences on the clinical and functional results of tumor resection and endoprosthetic reconstruction performed after oncological reasons.

\section{PATIENTS AND METHODS}

Between 2011 and 2018, we retrospectively analyzed 14 patients who underwent tumor resection and endoprosthetic reconstruction in our clinic for oncological reasons around the elbow joint. Demographic information, diagnosis, presence of pathological fracture at the time of diagnosis, positivity of surgical margins, chemotherapy and radiotherapy, functional scores, recurrence and complications were recorded. 2 patients were excluded from the study as they did not satisfy the necessary criteria.

\section{Surgical Treatment}

In our clinic, we prefer lateral surgical approach that continues along the ulna bone, extending proximally towards the deltopectoral. After skin incision, the radial nerve was released by finding it between the brachialis and brachioradialis muscles. Neurovascular structures were revealed by entering the interval between the biceps and triceps muscles proximally. Median, ulnar and medial antebrachial nerves were isolated and suspended. The brachial artery and vein were carefully dissected from the pseudocapsule in the soft tissue of the tumor. Meanwhile, care must be taken not to damage the median nerve. The biceps muscle should be protected. Pronotor teres and common flexor muscles should be deviated medially. If there is resection in the lateral part of the brachiradialis and common extensor group, the posterior intraosseous nerve should be preserved.
The triceps muscle was released from the distal humerus and usually the medial head is completely or partially excised due to tumor spread. Lateral and long head were generally preserved. The adhesion of the triceps tendon to the olecranon should be maintained. It should not be osteotomized. Subsequently, the joint capsule was opened, and the humeroulnar and radiohumeral joints are disarticulated. Humerus and ulna are resected and prepared to provide a negative surgical margin. Modular segmental distal humerus resection prosthesis was used in the treatment of the formed cavity. Joint movements are controlled. A good bleeding control should be done. The brachioradialis and extensor carpi radialis muscles are stressed into the remaining biceps and triceps muscles, and the elbow joint prosthesis is covered. While performing these procedures, the elbow should be at 60 degrees of flexion and full supination.

\section{Statistical analysis}

SPSS 22 program was used for the statistical analysis of the research data. In the descriptive statistics section, categorical variables are presented as numbers, percentages, and continuous variables are presented with mean \pm standard deviation and median (smallest-largest value). The consistency of the continuous variables with the normal distribution was evaluated using visual (histogram and probability plots) and analytical methods (Kolmogorov-Smirnov / Shapiro-Wilk tests). As a result of the normality analysis, it was determined that the data of continuous variables were not normally distributed. The relationship between numerical variables was evaluated by Spearman Correlation Analysis. Survival rates were calculated by the Kaplan-Meier method. The survival times of some predictors were compared using the log-rank test. In this study, statistical significance level was accepted as $p<0.05$.

\section{RESULTS}

A total of 14 patients, 7 of whom were female and 7 were male, with an average age of $60.6 \pm 14.2$, with endoprosthetic reconstruction were included in the study. Half of the patients had pathological fractures at admission. While 4 of the patients were primary tumors (1 fibromixoid sarcoma, 1 leimyosarcoma, 1 multiple myeloma and 1 ewing sarcoma), 10 were distant organ metastases (4 breast cancer, 3 lung cancer, 1 stomach cancer, 1 renal cell cancer and 1 thyroid cancer). Modular segmental distal humerus resection prosthesis was applied to all patients included in the study (Figure 1). Surgical margins 


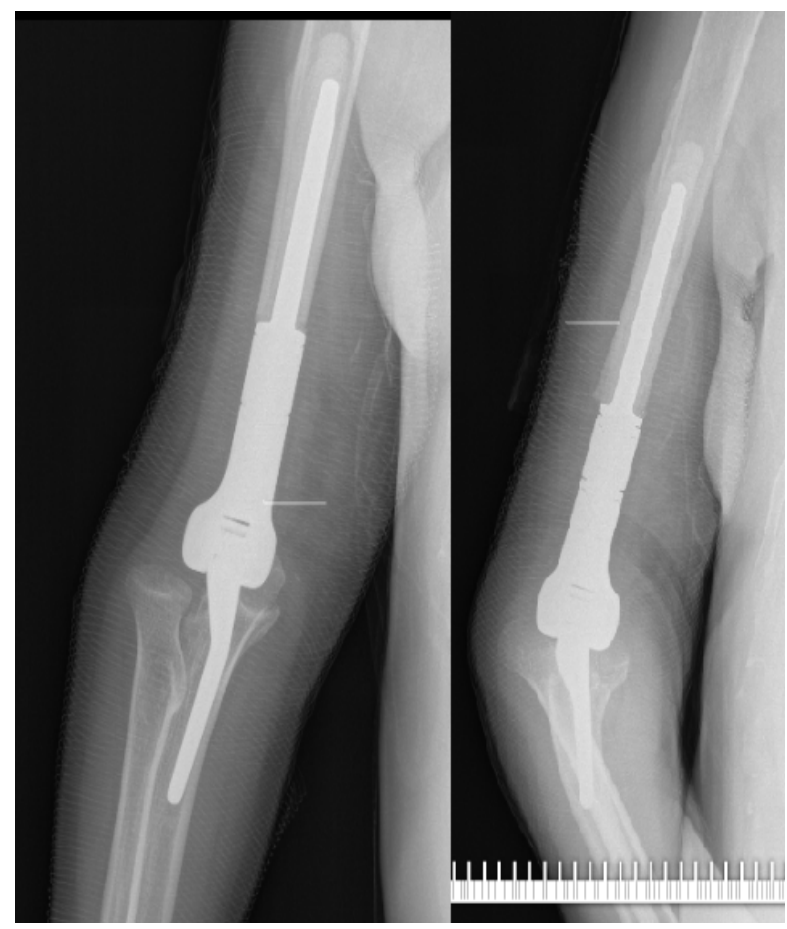

Figure 1. Postoperative direct $\mathrm{x}$-ray view of the modular segmental distal humerus resection prosthesis

were positive in 2 patients. In postoperative followup, only 1 patient developed complications and wound separation due to infection. It was operated by plastic surgery. 9 patients received neoadjuvant chemotherapy, 2 patients received neoadjuvant chemotherapy and radiotherapy, and 3 received only radiotherapy. All of the patients started passive movements at the 3rd week and active movements at the 6th week. The minimum follow-up period of the patients was 7 months, and the maximum followup period was 55 months. The mean score of Mayo elbow performance score (MEPS) of the patients was $67.5 \pm 12.0$ (range, 45-90), and the average of Musculoskeletal Tumor Society score (MSTS) was $19.4 \pm 2.3$ (range, 16-24). It was found that age did not have a statistically significant relationship with the MEPS score $(r=-0.136, p=0.664)$ and MSTS score $(r=0.048, p=0.870)$. It was noteworthy that there was a significant positive correlation between the followup time and the MEPS score $(r=0.552, p=0.041)$ and the MSTS score $(r=0.589, p=0.027)$. It was observed that the MEPS scores and MSTS scores of the patients who were followed for a longer period were higher. Recurrence occurred at follow-up in 3
Table 1. Demographic and Clinical Features

\begin{tabular}{|c|c|}
\hline \multicolumn{2}{|l|}{$\mathrm{N}=14$} \\
\hline \multicolumn{2}{|l|}{ Age, years } \\
\hline Mean \pm sd & $60.6 \pm 14.2$ \\
\hline Median(min-max) & $63.0(28.0-83.0)$ \\
\hline \multicolumn{2}{|l|}{ Gender, $n(\%)$} \\
\hline Male & $7(50.0)$ \\
\hline Female & $7(50.0)$ \\
\hline \multicolumn{2}{|l|}{ Side, $n(\%)$} \\
\hline Right & $7(50.0)$ \\
\hline Left & $7(50.0)$ \\
\hline \multicolumn{2}{|c|}{$\begin{array}{l}\text { Pathological fracture } \\
\text { on admission, } n(\%)\end{array}$} \\
\hline No & $7(50.0)$ \\
\hline Yes & $7(50.0)$ \\
\hline \multicolumn{2}{|l|}{ Primer, n(\%) } \\
\hline Primer & $4(28.6)$ \\
\hline Metastasis & $10(71.4)$ \\
\hline \multicolumn{2}{|c|}{ Surgical border, n(\%) } \\
\hline Negative & $12(85.7)$ \\
\hline Pozitive & $2(14.3)$ \\
\hline \multicolumn{2}{|c|}{ Postop complications, $n(\%)$} \\
\hline No & $13(82.9)$ \\
\hline Yes (Separation) & $1(7.1)$ \\
\hline \multicolumn{2}{|l|}{ MEPS score } \\
\hline Mean \pm sd & $67.5 \pm 12.0$ \\
\hline Median(min-max) & $70(45-90)$ \\
\hline \multicolumn{2}{|l|}{ MEPS score } \\
\hline <60 (weak) & $3(21.4)$ \\
\hline$\geq 60$ (enough) & $11(78.6)$ \\
\hline \multicolumn{2}{|l|}{ MTST score } \\
\hline Mean \pm sd & $19.4 \pm 2.3$ \\
\hline Median(min-max) & $20(16-24)$ \\
\hline \multicolumn{2}{|l|}{ MTST score } \\
\hline$<20$ (median) & $6(42.9)$ \\
\hline$\geq 20$ (median) & $8(57.1)$ \\
\hline \multicolumn{2}{|l|}{ Follow-up time } \\
\hline Mean \pm sd & $19.6 \pm 14.1$ \\
\hline Median(min-max) & $13.5(7-55)$ \\
\hline \multicolumn{2}{|l|}{ Recurrence, $n(\%)$} \\
\hline No & $11(78.6)$ \\
\hline Yes & $3(21.4)$ \\
\hline \multicolumn{2}{|l|}{ Exitus, $n(\%)$} \\
\hline No & $7(50.0)$ \\
\hline Yes & $7(50.0)$ \\
\hline
\end{tabular}

patients and exitus at follow-up in 7 patients (Table 1). In this study, the median survival of patients was 44 months. The 1 -year survival rate was $70.1 \%$ while the 3 -year survival rate was $54.5 \%$. Considering gender, age, pathological fracture and primary tumor status at admission, no significant difference was found between survival times and speeds ( $p>0.05)$. In those with a MEPS score below 60 and with a MSTS score below 20, it was found that overall survival times were shorter, and survival rates were lower statistically $(p=$ 0.005 and $p=0.003$ ) (Table 2). 
Tablo 2. Evaluation of overall survival rates and log rank test results

\begin{tabular}{|c|c|c|c|c|}
\hline Total $\mathrm{N}=37$ & Log Rank Test P & $\begin{array}{c}\text { Overall survival, month } \\
\text { Median(\%95 GA) }\end{array}$ & $\begin{array}{l}\text { 1-year survival } \\
\text { rate, } \%\end{array}$ & $\begin{array}{l}\text { 3-year survival } \\
\text { rate, } \%\end{array}$ \\
\hline Patients & & $44.0(13.1-74.9)$ & 70.1 & 54.5 \\
\hline Gender & 0.706 & & & \\
\hline Male & & $33.7 \pm 8.9^{*}$ & 85.7 & 51.4 \\
\hline Female & & 44.0 (NA) & 57.1 & 57.1 \\
\hline Age & 0.447 & & & \\
\hline$<65$ & & $38.9 \pm 7.6^{*}$ & 64.8 & 64.8 \\
\hline$\geq 65$ & & $13.0(10.9-15.1)$ & 80.0 & 40.0 \\
\hline $\begin{array}{l}\text { Pathological } \\
\text { fracture on } \\
\text { admission }\end{array}$ & 0.359 & & & \\
\hline No & & $13(8.7-17.3)$ & 53.6 & 35.7 \\
\hline Yes & & $44.0(\mathrm{NA})$ & 85.7 & 71.4 \\
\hline Primer, n(\%) & 0.347 & & & \\
\hline Primer & & $40.3 \pm 11.9^{*}$ & 66.7 & 66.7 \\
\hline Metastasis & & $13.0(0-27.6)$ & 70.0 & 50.0 \\
\hline MEPS score & 0.005 & & & \\
\hline <60 (weak) & & $9(5.8-12.2)$ & 33.3 & 0 \\
\hline$\geq 60$ (enough) & & $44(0-88.7)$ & 80.0 & 70.0 \\
\hline MTST score & 0.003 & & & \\
\hline$<20$ (median) & & $11.0(7.1-14.9)$ & 44.4 & 0 \\
\hline$\geq 20$ (median) & & $44(0-90.5)$ & 87.5 & 43.8 \\
\hline
\end{tabular}

NA: Not Available * Since the median survival time could not be reached, the mean \pm standard error was presented

\section{DISCUSSION}

Large series are difficult to reach since the elbow circumference is rare as a malignant tumor. The operations of this region are difficult because it contains anatomically complex and vital vascular nerve structures. Since many malignant primary or metastatic bone tumors cause vascular nerve involvement in this region, functional losses can be observed in the related extremity (6). The main finding of this study was that pain and functional results are satisfactory in patients who undergo tumor resection and endoprosthetic reconstruction due to malignant tumor around the elbow.

Traditional elbow prostheses fail after large bone resections for oncological reasons (7). Arthrodesis is less preferred because it does not maintain the functionality of the elbow joint (3). Before the advent of neoadjuvant chemotherapy and radiation, amputation often is the best method of achieving local control. The current multidisciplinary treatment approach to patients with musculoskeletal tumors now allows limb salvage as an option in the majority of patients. This is extremely important for patients with upper extremity tumors because limb salvage allows a much greater degree of independence in daily activities compared to above elbow amputation, shoulder disarticulation, or forequarter amputation. The purpose of limbsparing surgery is to achieve a functional elbow joint by providing local control of the disease. The literature suggests tumor resection and endoprosthetic reconstruction (4-6). In our study, we performed tumor resection and endoprosthetic reconstruction in a total of 14 patients 4 of whom were primary tumors and 10 of whom were metastases. Primary malignant tumors and metastases around the elbow area are referred to the clinic with pain, swelling and pathological fracture. Weber et al. (6) showed that $10(43 \%)$ of 23 patients who operated on elbow area due to malignant tumor presented with a pathological fracture. In our study, 7 patients $(50 \%)$ presented with a pathological fracture.

Kulkarni et al. (4) study showed that the functional results of 10 patients operated for elbow circumference tumors reported $73 \%$ as good results. Sperling et al. (8) followed 13 patients operated for an elbow circumference tumor for an average of 2.5 years and reported good functional results. According to the results of Weber et al. (6) study, the MSTS score was 23 of 30 points $(77 \%)$ in the 12 living patients followed up for a mean of 46 months (range, 24-124 months). Hanna et al. (9) found the MSTS score as $76 \%$ in 11 patients who followed an average of 5.8 years. Athwal et al. (10) found the MEPS score as 75 postoperatively. In our study, the MEPS score of 14 patients, which we followed for an average of 19 months, was $67.5 \pm 12.0$ (range, 45-90), and the MTST score was $63.3 \%$ satisfactory. It was observed 
that the MEPS score and MSTS scores of the patients who were followed for a longer period were higher. We think that the reason for this is that patients who were followed for a long time received longer physical therapy.

Tumor resection and endoprosthetic reconstruction are difficult due to the complex anatomy of the elbow circumference and its proximity to the vascularnerve. Therefore, complications and recurrences are high (6-10). Athwal et al. observed recurrence in $5(25 \%)$ of 20 patients who underwent tumor resection and endoprosthetic reconstruction due to elbow circumference tumor (10). Weber et al. (6) showed, the local recurrence rate was 19\% (four of 21 patients). Kulkarni et al. (4) did not report infection, relapse and amputation, but reported revision due to aseptic relaxation. In our study, one patient developed separation at the wound site due to infection and the operation by a plastic surgery. This study has some limitations. It is primarily a retrospective study. Followup times were shorter due to patients with exitus, and the number of patients was also low.

As a result, pain and functional results are satisfactory in patients who undergo tumor resection and endoprosthetic reconstruction due to malignant tumor around the elbow. Moreover, an aggressive resection provides adequate surgical margins. It can provide a potential cure for primary malignant tumors that hold this region, but although it provides an adequate functional result in metastatic tumors, it does not contribute much to total life expectancy. In future studies, larger patient series are needed.

Conflict of interest: Authors declare that there is no conflict of interest between the authors of the article.

Financial conflict of interest: Authors declare that they did not receive any financial support in this study.

Address correspondence to: Coskun Ulucakoy, Department of Orthopaedics and Traumatology, Dr Abdurrahman Yurtaslan Ankara Oncology Training and Research Hospital, Ankara, Turkey

E-mail: coskunulucakoy@gmail.com

Phone number: +905323262305

\section{REFERENCES}

1. Casadei R, De Paolis M, Drago G, et al. Total elbow arthroplasty for primary and metastatic tumor. Orthop Traumatol Surg Res 2016;102(4):459-65.

2. Sperling JW, Pritchard DJ, Morrey BF. Total elbow arthroplasty after resection of tumors at the elbow. Clin Orthop Relat Res 1999;367:256-61.

3. Moghaddam-Alvandi A, Dremel E, Guven F, et al. Arthrodesis of the elbow joint. Indications, surgical technique and clinical results. Unfallchirurg 2010;113:300-7.

4. Capanna R, Muratori F, Campo FR, et al. Modular megaprosthesis reconstruction for oncological and nononcological resection of the elbow joint. Injury 2016;47:S7883.

5. Ross AC, Sneath RS, Scales JT. Endoprosthetic replacement of the humerus and elbow joint. J Bone Joint Surg $[\mathrm{Br}]$ 1987;69-B:652-5.

6. Weber KL, Lin PP, Yasko AW. Complex segmental elbow reconstruction after tumor resection. Clin Orthop Relat Res 2003;415:31-44

7. Morrey ME, Sanchez-Sotelo J, Abdel MP, et al. Allograftprosthetic composite reconstruction for massive bone loss including catastrophic failure in total elbow arthroplasty. J Bone Joint Surg Am 2013;95:1117-24.

8. Sperling JW, Pritchard DJ, Morrey BF. Total elbow arthroplasty after resection of tumours at the elbow. Clin Orthop 1999;367:256-61.

9. Hanna SA, David LA, Aston WJS, et al. Endoprosthetic replacement of the distal humerus following resection of bone tumours. J Bone Joint Surg Br 2007;89(11):1498-503.

10. Athwal GS, Chin PY, Adams RA, et al. Coonrad-Morrey total elbow arthroplasty for tumours of the distal humerus and elbow.J Bone Joint Surg [Br] 2005;87-B:1369-74. 